\title{
CONQUISTA CONTROL Y CONVICCIÓN: EL PAPEL DE LOS PARLAMENTOS INDÍGENAS EN MÉXICO, EL CHACO Y NORTEAMÉRICA
}

POR

\author{
CARLOS LÁZARO ÁVILA
}

\begin{abstract}
En este artículo se hace una evaluación del papel que desempeñaron los conflictos fronterizos en la toma de una serie de medidas para su resolución y que desembocaron en la adopción de un ámbito de consenso o diplomático. Se parte del primer conflicto fronterizo americano, el norte de México, para ilustrar las aceleradas soluciones que se hubo de adoptar para solventarlo. Sin embargo esas medidas tuvieron una honda repercusión en la metrópoli y se modificaron en fronteras posteriores como el Chaco, a caballo entre la política austriaca y la reformista borbónica. Por último, analizamos el caso de las posesiones españolas de Norteamérica donde el pactismo se tuvo que aplicar bajo la égida directa del reformismo borbónico que afrontó allí el difícil equilibrio de preservar sus dominios territoriales a la vez que sus intereses comerciales en un contexto político complejo.
\end{abstract}

Desde hace unos años, la historiografía americanista especializada en el mundo fronterizo está empezando a reconsiderar el papel de aquel conjunto de pueblos que no sólo fueron capaces de obviar el poder colonial español, sino también preservaron sus territorios y obligaron al sistema político-económico europeo a replantear sus directrices de dominación. Aunque la mayoría de los deseos de ocupación de las tierras ocupadas por tribus norteamericanas de las riberas del Mississipi, los apaches y chichimecas del septentrión mexicano, el abigarrado conjunto de bandas del Chaco, así como los mapuche y techuelches de uno y otro lado de la cordillera andina ubicada en el cono sur americano, fueron objeto de directrices geopolíticas que convirtieron en estratégicos sus territorios en uno u otro momento de los tres siglos de conquista y colonización, a este variado conjunto de pueblos indígenas siempre se les ha atribuido un papel pasivo en la historia. Desde los primeros escarceos con las bandas chichimecas en el siglo XVI, estos grupos fronterizos se convirtieron en sujetos susceptibles de ser perseguidos, esclavizados, deportados o eliminados física y culturalmente. La única relevancia que adquirían en la historiografía clásica de frontera era la de figurar como meros saqueadores objeto de expediciones pacificadoras que, en 
verdad, escondían un ansiado afán de globalización en la esfera política y económica de la colonia. Hoy en día, conferimos a aquellas sociedades indígenas fronterizas indómitas - léase libres - un papel más activo en su propia historia y en la del conjunto del continente americano. Durante casi tres siglos mantuvieron con los hispanocriollos un pugna dialéctica de guerra y paz cuyo aspecto más relevante fue la aparición de una nueva forma de entendimiento, el parlamento. Esta institución política ya se hallaba presente en esencia tanto en las culturas indígenas americanas como en la europea, pero en el ámbito fronterizo americano adquirió un nuevo papel, con reglas distintas aceptadas por ambos bandos, y cuya expresión histórica se encuentra en los más de doscientos tratados de paz que se conservan en los archivos que, entre otros aspectos destacados, reflejan, aunque muy matizado por la fuente de transmisión, un elemento muy preciado por los investigadores americanistas: la palabra indígena. Dado que ya hemos tenido ocasión de hacer un estudio global sobre el corpus diplomático fronterizo americano y que en este número se hace alusión al Cono Sur americano, nos referiremos a continuación a cuál fue la actitud de la corona acerca de este tipo de indios a partir de los aspectos más llamativos de los tratados surgidos en el septentrión mexicano, el Chaco y Norteamérica.

\section{RAZONES PARA UN PARLAMENTO}

A lo largo de los tres siglos de la colonia, cuando los hispanocriollos fueron conscientes de la imposibilidad de conquistar o controlar a los indios fronterizos, pese al empleo de la violencia ideológica y práctica extrema centrados en la esclavitud y muerte de un pueblo bárbaro, se vieron obligados a poner en funcionamiento la práctica de los tratados, La razón era evidente: el parlamento constituyó el mejor medio para intentar controlar a unos grupos indígenas irreductibles en quienes se concentraban tres grandes problemas para la administración colonial. El primero de ellos era que su conocida animadversión a la colonia era un foco político subersivo que constituía un potencial aliado de los enemigos de España en América. En segundo lugar, estas regiones fronterizas libres agrupaban importantes núcleos de población que dejaban de ser clientes directos del mercado colonial, y cuyas actividades de transacción y contrabando quedaban fuera del control fiscal colonial. Por último, los territorios controlados por estos grupos insurrectos no sólo se convirtieron para los indígenas en un reducto cultural de resistencia que ofrecía refugio cultural y religioso del dogma cristiano y de las formas culturales hispanocriollas que imponía la colonia, sino que también abrieron sus puertas a todos aquellos elementos sociales rechazados por la sociedad estamental hispanocriolla (renegados, esclavos prófugos, maleantes y cautivos). En este sentido, para contrarrestar esta compleja problemática fronteriza colonial, que incluía siempre, en mayor o menor grado, los tres problemas cita- 
dos anteriormente, queremos señalar que no hubo una política uniforme hasta la primera mitad del siglo XVII en que el famoso parlamento de Quillín (1641) celebrado con los mapuche de la Araucanía sentó las bases de la tratadística hispanocriolla en América. Fue a partir de la celebración de ese acuerdo, que, por otra parte, constituye el único documento diplomático suscrito con unos indígenas que recoge J.A. Abreu y Bertodano en su compilación de tratados europeos ${ }^{1}$, cuando hemos empezado a detectar documentalmente la existencia de más tratados en la América Hispana que reunen, entre un conjunto de elementos novedosos, dos características que los diferencian de acuerdos consensuados anteriormente: ya no se plantean desde una óptica local, puesto que empieza a intervenir más la metrópoli, y se pretende convencer a los díscolos indígenas de que acepten el beneficioso status de vasallo libre aliado de la corona española a la que debe defender de todos sus enemigos. No obstante, este proceso diplomático encaminado a crear un ámbito de consenso en la América Hispana tuvo su propia génesis interna cuyo punto de partida es el pacto local que hace un jefe militar y que finaliza con la intervención de las más altas autoridades coloniales en nombre de una corona que refrenda en la metrópoli una manera de controlar aquellas regiones más díscolas de su imperio mediante un arma incruenta: la persuasión. A continuación, vamos a contemplar la casuística particular del norte de México, el Chaco y las posesiones de Norteamérica, donde podremos contemplar los diferentes desarrollos del proceso diplomático. Pero antes queremos hacer unas consideraciones generales previas que son necesarias para comprender los contextos que vamos a analizar.

Cuando en el primer siglo de ocupación se iniciaba la etapa de consolidación de la colonia española, tanto en los antiguos imperios prehispánicos como en aquellos territorios donde la población sedentaria posibilitaba el establecimiento de la encomienda, los españoles tuvieron que hacer frente a un nuevo tipo de conflicto en cuya resolución el juego diplomático desempeñó un papel crucial. Este particular enfrentamiento se acota cronológicamente entre la fecha de inicio de la cruenta campaña del norte de México, conocida como Guerra Chichimeca (1550-1600), que marcaría el inicio de una sucesiva aparición de complejos conflictos en las zonas limítrofes del imperio español en América, y 1700, momento en el que la dinastía real de los Borbones ocupa el trono vacante de España, hecho que antecede a la implantación en América del conjunto de reformas centralizadoras que se dictaban en Madrid. En este caso, y al igual que ocurriera en la etapa antillana, la diplomacia fronteriza fue seguida de la aparición de una nueva concepción jurídica e ideológica suscitada por el hecho crucial de que los hispanocriollos tuvieron que hacer frente a un tipo de aborígenes muy diferentes a los que se englobaban en las estructuras virreinales: los indígenas fronterizos.

1 José Antonio ABReU y BertodAno, Colección de los tratados de paz, alianza, neutralidad en el Reynado del S.Rey D. Phelipe IV. 12 vols. Madrid, 1746. Volúmen IV: p. 416.

R. I., $1999, \mathrm{n}^{\circ} 217$ 
La mayoría de las sociedades fronterizas con las que se enfrentaron los españoles no disponían de ejércitos tan numerosos y disciplinados como los mexica e inca. Además, gran parte de ellas se caracterizaban porque su poder político no era coercitivo y estaba atomizado; estos grupos se estructuraban en bandas y tribus nómadas o seminómadas que se dedicaban a la caza y recolección, aunque también hubo algunas que practicaban la agricultura itinerante y la horticultura. En este sentido, el proceso de negociación no sólo estuvo dificultado por el inicial choque bélico en el que se vieron envueltos ambos bandos, fuente de odios y recelos imperecederos que afectarían a los tratados acordados, sino también por el hecho de que la fragmentación política de estas bandas, tribus y cacicazgos indígenas fronterizos dio lugar al establecimiento de múltiples acuerdos cuya perdurabilidad dependía de los cambiantes intereses locales de los indígenas e hispanocriollos. Pese a ello, esta serie de pueblos a los que los europeos también quisieron englobar en sus dominios resultaron ser hábiles combatientes; sus ataques asolaron caminos reales, estancias y grandes núcleos de población colonial, desapareciendo sin dejar huellas que guiaran a las expediciones punitivas que iban en su busca. En un estudio anterior ${ }^{2}$, hemos tenido ocasión de analizar comparativamente a sociedades indígenas americanas que comparten esas características y que, además, son los principales protagonistas de los tratados fronterizos que analizamos a continuación: araucanos (centro-sur de Chile), chichimecas (septentrión de México), ${ }^{3}$ chaqueños y chiriguanos (sureste del virreinato del Perú) y pampas (Argentina). En nuestro estudio hicimos hincapié en varios hechos relevantes que también se convirtieron en común denominador de estas culturas: a) intentaron ser asimiladas o mantuvieron enfrentamientos bélicos $\mathrm{y}$, en consecuencia, hicieron pactos con entidades imperiales o estatales prehispánicas ${ }^{4}$, b) esas entidades transmitieron una imagen subjetiva que se refleja en los apelativos despectivos - chichimecas, chiriguanos, guaycurúes - que asimiló la sociedad hispanocriolla, y c) la mayoría de estas comunidades incorporaron paulatinamente numerosos elementos de la cultura española - principalmente ganadería vacuna y lanar, caballos y armas - utilizándolos exitosamente en su resistencia frente al avance de los europeos. Además, en ese trabajo resaltamos que este proceso de aculturación selectiva favoreció un proceso de etnogénesis que desembocó en la aparición de unas sociedades aborígenes cuyas bases sociopolíticas, económicas y culturales eran muy diferentes a las de la época prehispánica, influyendo determinantemente en el proceso pactista ${ }^{5}$.

2 Carlos LÁZARo Ávila Las fronteras de América y los «Flandes Indianos». Consejo Superior de Investigaciones Científicas. Madrid, 1997.

3 LÁZARO [2] 44-50.

4 LÁZARO [2] cap.2; p. 99-107.

5 Para el caso araucano ver Carlos LÁzARo Ávila La transformación sociopolítica de los araucanos (Siglo XVII), Tesis Doctoral. Universidad Complutense de Madrid. Madrid, 1995 y Guillaume BOCCARA, Des Reche aux Mapuche: analyse d'un processus d'ethnogenèse (Change-

R. I., $1999, \mathrm{n}^{\circ} 217$ 
A medida que se consolidaba la colonia en el Nuevo Mundo, la administración hispana, dentro de la nueva geopolítica colonial que se iba configurando a partir de la segunda mitad del siglo XVI, iba tomando conciencia tanto de los puntos débiles de sus posesiones como de las nuevas atracciones estratégicas y económicas que emanaban de los territorios habitados por estas sociedades tan peculiares. Los yacimientos argentíferos del norte de México, las importantes cabañas ganaderas que poblaban el Tucumán —que abastecían la infraestructura de la minería de Potosí- y el control del estrecho de Magallanes, llave de acceso al Pacífico, se convirtieron en objetivos de primer orden, tanto para los intereses de la política exterior de la Corona, como para la política de actuación local de la administración colonial americana. Los intentos de controlar estos estratégicos territorios provocaron largas y sangrientas guerras donde se emplearon numerosos recursos humanos y económicos. La importancia y gravedad de este tipo de luchas llegó a ser tan relevante que, en el caso concreto de Chile, el jesuita Diego de Rosales llegaría a comparar la lucha contra los araucanos con las guerras que mantenía la casa de Austria con las provincias septentrionales de los Países Bajos, y lo denominó como el Flandes Indiano. Estos conflictos fronterizos se convirtieron paulatinamente en los onerosos y sangrientos «Flandes» de la Corona española en América y, al igual que ocurrió en Europa, los españoles se vieron obligados a llegar a un acuerdo diplomático con ellos.

\section{EL SEPTENTRIÓN NOVOHISPANO: LA CONFORMACIÓN DE LOS FACTORES DEL CONSENSO.}

La Guerra Chichimeca del norte de México (1550-1600) fue el primero de los conflictos fronterizos al que los españoles tuvieron que hacer frente en América. El descubrimiento de minas de plata en las inhóspitas montañas de Zacatecas dio lugar al desplazamiento de un considerable número de hispanocriollos e indígenas deseosos de mejorar su situación socioeconómica. Desde que se puso en marcha la extracción del mineral y adquirieron regularidad los envíos de plata a la capital del virreinato novohispano, la administración pretendió mantener un ritmo continuado de la explotación con el fin de satisfacer las exhaustas arcas de la metrópoli empeñadas por los sucesivos conflictos europeos. Al principio, las dispersas comunidades chichimecas que habitaban el septentrión mexicano, que nunca habían sido dominadas por el Imperio Azteca, aceptaron la presencia de colonos y mineros. Pero en el momento en que los convoyes de suministros procedentes de México comenzaron a aumentar su regularidad y que a sus peticiones de alimentos se les añadieron los numerosos abusos que se cometieron contra los

ments et continuités chez les Indiens du centre-Sud du Chili durant l'époque coloniale, XVIèmeXVIIIème siècle), Tesis Doctoral. EHESS. París, 1996. 
poblados indígenas, les obligaron a declarar la guerra abierta a los recién llegados. Los hispanocriollos respondieron rápidamente a los ataques indígenas, sumiendo a la frontera norte de México en una guerra cruenta que se prolongaría durante medio siglo.

El primer choque fronterizo hispano-indígena de América ha sido ampliamente estudiado por Philipp W. Powell en su libro, ya clásico, de La Guerra Chichimeca (1550-1600). Este autor ha comentado que en el problema chichimeca los españoles utilizaron la fuerza militar de una manera expeditiva pero descoordinada, combinándola con una medida que contribuyó enormemente a la dilatación y recrudecimiento de la guerra: la esclavitud de los indígenas capturados en la contienda. ¿Cuál fue el origen de esta medida? Podemos responder diciendo que la conversión en esclavos de los indígenas insumisos respondió a la necesidad local de ofrecer un aliciente a las tropas que se quisieran enganchar en las expediciones punitivas. El conjunto de bandas nómadas que agrupaba el término chichimeca tenían una escasa cultura material carente de objetos de valor y los jefes de las expediciones tuvieron que recurrir a la esclavitud indígena para distraer hombres de las imaginarias fortunas que podían proporcionar los focos mineros. Pero fueron también los hacendados, así como los religiosos franciscanos y agustinos, los que propugnaban que se hiciera una guerra sin cuartel a los chichimecas y se les convirtiera en esclavos.

Además, como ha señalado Powell, a las continuas demandas que hicieron los hacendados para que se pusiera freno a los ataques chichimecas pronto se le unieron las voces de destacados dirigentes de las iglesia novohispana que, basándose en las atrocidades de los indígenas, apoyaban la guerra justa y su conversión a la esclavitud ${ }^{6}$ y argumentaban que era necesario enviarlos a las minas para preservar a los indígenas sedentarios del sur de estos trabajos tan penosos. Pese a todo, la guerra a sangre y fuego - como fue conocida en México la combinación militar y esclavista - no lograba acabar con las numerosas incursiones que los indígenas realizaban contra los asentamientos hispanocriollos. La dura respuesta de la administración colonial acendró los ánimos de resistencia de los chichimecas; al mismo tiempo, en el seno de estas bandas nómadas se producía una evolución sociocultural como consecuencia del proceso de contacto con los españoles e indígenas hispanizados que trajo consigo una transformación en la dirección política y una mejora en el campo bélico. Los cambios operados entre los chichimecas dieron lugar a un recrudecimiento de la guerra que fue contestado por los españoles con el refuerzo de su política bélico-esclavista?

Las protestas de los frailes dominicos y los escasos partidarios de aplicar una línea pacífica y comprensiva con los chichimecas fueron ganando adeptos en la corte. Buena prueba de ello es que, en los últimos años del siglo XVI, durante los

\footnotetext{
6 Philipp W. Powell La Guerra Chichimeca (1550-1600), FCE. México, 1994, pp. 103 y ss.

7 LÁZARO [2] pp. 55 y ss.
}

R. I., 1999, n. $^{\circ} 217$ 
gobiernos de los virreyes Alvaro Manrique de Zúñiga, Marqués de Villamanrique (1585-1590) y Luis de Velasco, (1590-1595) se produjeron cambios que alteraron notablemente el rumbo de este conflicto. Por un lado, el contingente militar preparado contra los chichimecas se hizo más efectivo con la incorporación de voluntarios militares y civiles tlaxcaltecas. Estas agrupaciones indígenas procedían del valle de México y, además de servir como tropas auxiliares a los españoles, se les asentó en pueblos junto a la línea de presidios que se iban estableciendo en los puntos clave de la frontera como ejemplo a imitar por parte de los chichimecas pacificados. Más tarde, los auxiliares indígenas tlaxcaltecas recibieron la ayuda de un grupo indígena local, los otomíes, conformando de una manera muy temprana una de las unidades básicas - unión de grupos indígenas foráneos y locales en el bando español- que participará tanto en la lucha como en la posterior negociación de los tratados de paz con los indios fronterizos. En realidad, los otomíes se convirtieron en el verdadero antecedente americano de la figura fronteriza de los indios amigos que desempeñarán un papel muy destacado en la frontera de la Araucanía.

Junto a este frente militar hay que destacar la activa intervención de franciscanos y jesuitas —estos últimos, de manera más tardía - que, ayudados por la política conciliatoria establecida por los virreyes Villamanrique y Velasco, fundaron una serie de misiones protegidas por presidios militares a las que se pretendía atraer a los nómadas chichimecas a cambio del reparto de ropas y alimentos. Según Powell, la documentación habla de acuerdos pacíficos o tratados con los indígenas, pero no nos han legado constancia de ellos. Así pues, es más patente para el fin de la guerra el efecto de una política de dádivas que, por otro lado, ya se había puesto en práctica en años anteriores, a la que se sumaron los efectos de la terrible mortalidad que asolaba a los chichimecas como consecuencia de la transmisión de enfermedades de origen europeo.

Las consecuencias de este doble frente militar y religioso dio lugar a que numerosos grupos chichimecas abandonaran las armas y comenzaran a establecerse junto a las misiones, donde aprendieron la agricultura y empezaron a ser catequizados. A principio del siglo XVII, la calma volvió a reinar momentáneamente en la región. En realidad, los españoles habían conseguido garantizar la extracción regular del mineral y su transporte a México a costa de que los indígenas más irreductibles fueran expulsados a territorios situados más al norte, pero ello no impidió la existencia de un cierto clima de inseguridad que aún perduraría durante mucho tiempo. Esta situación ha sido calificada por W. Borah como de paz precaria $^{8}$, y refleja el hecho de que la administración española, pese a un acuerdo pacífico inicial, no supo aportar una respuesta adecuada para solventar los graves

8 W. BORAH, La defensa fronteriza durante la gran rebelión tepehuana, Historia Mexicana, vol. XVI. nº1. México, 1966, p.15.

R. I., $1999, \mathrm{n}^{\circ} 217$ 
problemas que les habían proporcionado unas bandas nómadas después de su exitosa conquista del Imperio Azteca.

Pese a la posible existencia de acuerdos verbales entre los oficiales de la hueste hispanocriolla y los indígenas, el episodio de la Guerra Chichimeca, pese a las referencias dadas, parece que se solucionó sin dar lugar a la suscripción de un tratado escrito, pero lo que nos interesa destacar ahora es que el primer ejemplo de guerra fronteriza aportó una serie de factores que antecederían a la creación de un medio de relación por encima de la violencia y que guiarían los posteriores procesos diplomáticos. El primero de ellos se refiere a la dualidad militarreligiosa empleada para tratar de solucionar los posteriores conflictos fronterizos; en ella empezarán a jugar un destacado papel los aliados indígenas locales o indios amigos, que se convertirán en los primeros interlocutores o intérpretes del diálogo que surgirá entre los dos mundos. En segundo lugar la importancia que tiene el hecho de que ambas culturas acepten las existencia de un ámbito de discusión donde tratar sus diferencias. el mejor ejemplo que disponemos es la convocatoria de una reunión política hispano-indígena ocurrida en 1616 durante la rebelión tepehuana; se trata de una Junta de capitanes chichimecas organizada por los españoles para evitar cualquier tipo de ayuda por parte de los asentamientos sureños hacia los rebeldes tepehuanes. En esta reunión los dirigentes chichimecas, tras prometer fidelidad al gobernador, recibieron numerosos regalos (ropa, tejidos y alimentos). Este hecho se convirtió en el precedente directo de los institucionalizados donativos entregados a los dirigentes indígenas de otros territorios americanos después de los tratados de paz, y que ante la falta de reciprocidad por parte de los indígenas, fueron considerados por algunos colonos y funcionarios locales como los onerosos tributos que tenían que pagar los españoles para que los aborígenes se mantuvieran en paz.

La implantación de un sistema diplomático con los indígenas rebeldes debió de ser lo suficientemente significativo como para que a fines del siglo XVI apareciese, de la mano del capitán Bernardo Vargas Machuca, una recomendación formal sobre cómo había de llevarse a cabo y qué objetivos había de contener un tratado de paz con los indígenas. En su obra Milicia y descripción de las Indias $(1599)^{9}$, este militar advertía que los dirigentes siempre deben buscar la paz con los indígenas para poder predicar el Evangelio y garantizar el vasallaje, obediencia y tributo del aborigen hacia el rey. Vargas Machuca hacía constar que el indígena debe tener un exacto conocimiento de los contenidos de la paz -advirtiéndoles las calidades y condiciones de ellas - pero no deja de ocultar la parte interesada del contrato: el oficial o caudillo que la lleve a cabo debe perseguir la debilidad del enemigo y evitar su alianza con otra nación. Además, este capitán advertía a los encargados de llevar a cabo los tratados que debían conocer las características de los indígenas con los que se iba concertar el acuerdo, haciendo

9 Bernardo de VARgas MachuCA, Milicia y descripción de las Indias, Madrid, [1599], 1892. 
especial hincapié en aquellos que hubieran violado pactos anteriores, para quienes recomendaba una amplia demora a la hora de admitir sus peticiones pacíficas. Finalmente, expresaba cuáles eran los puntos cruciales que debía contener todo tratado de paz; dada su relevancia enumeramos los más importantes:

$1^{\circ}$ - La paz se asentará por escrito, siendo autentificada mediante un escribano y testigos.

$2^{\circ}$ - Los caciques y principales, en su calidad de representantes del resto de su comunidad, dan la paz, obediencia y vasallaje al rey, comprometiéndose a respetarla para con el resto de sus súbditos y aliados indígenas.

$3^{\circ}$ - No tomarán las armas contra los españoles ni abandonarán sus asentamientos.

$4^{\circ}$ - En caso de infringir el acuerdo, los principales inculpados serán los caciques, y aquellos dirigentes que conocieran los motivos de la alteración y no lo comunicaran serían desposeídos de sus cargos.

$5^{\circ}$ - Los indígenas están obligados a acudir a todos los llamamientos de la justicia.

$6^{\circ}$ - Como garantía del acuerdo se les exigirá a los caciques y principales que entreguen a sus hijos en calidad de rehenes.

Vargas Machuca especifica que la formalización del acuerdo lo llevará a cabo el oficial español abrazando a todos los caciques al tiempo que se hace una salva de armas de fuego como expresión de alegría; después, se invitaría a los caciques indígenas a un convite que culminaría con la entrega de presentes de cosas de rescates que ellos estimen ${ }^{10}$. Como se puede apreciar los términos estipulados por el capitán español bien pueden incluirse dentro del concepto de capitulaciones porque, exceptuando el compromiso que Vargas Machuca expresa respecto a que los representantes españoles deben garantizar a los indígenas que el rey les protegería y defendería de sus enemigos, el resto eran claras obligaciones que debían cumplir los aborígenes. Cabe señalar que no hay mención expresa de una alianza militar hispano-indígena y tampoco se alude a la condición jurídica en la que quedarían los indios, aunque sí se expresa claramente la entrega de rehenes. Éstos no sólo constituyen una garantía del acuerdo, sino que, una vez aculturados, servirían para cimentar las bases del poder español entre las comunidades sometidas. Las razones por las que consideramos que no hay mención explícita tanto a la situación jurídica como a la ayuda militar mutua obedece al hecho de que Vargas Machuca estima que los términos de este tratado conllevan, implícitamente, la total subyugación de los indígenas al poder español. La experiencia posterior demostraría que estas dos cuestiones tuvieron que inscribirse claramente en los

10 Idem, pp. 11-13. 
términos de los tratados o capitulaciones suscritos con los indígenas a consecuencia de la falta del sometimiento de éstos al dominio español; además, los hispanocriollos también comprobaron reiteradamente que las promesas de paz que los caciques daban en nombre de sus súbditos no se correspondían con la existencia de un poder coercitivo que garantizara su perdurabilidad.

Así, podemos apuntar que, desde el fin de la Guerra Chichimeca, la solución que aplicaron los españoles para resolver los conflictos fronterizos del siglo XVII se definió por su carácter dual y homogéneo. Dual, porque si exceptuamos las primeras actividades de los jesuitas en la Pampa, en el resto de los ámbitos fronterizos se produjo la alternancia entre una fase militar inicial, definida por sus violentos peditivos, seguida rápidamente por la actuación de los misioneros. La solución también fue homogénea porque después de haber pacificado el territorio septentrional mexicano, los españoles creyeron haber encontrado la manera adecuada de resolver todos aquellos conflictos que habían empezado a surgir en los diferentes ámbitos fronterizos de la América española y que, en principio, presentaban características similares a las encontradas en la frontera norte de Nueva España en lo que se refiere a pueblos nómadas o seminómadas gobernados por un sistema de behetrías.

La experiencia diplomática obtenida en el norte de México, pese a sus tardíos encuentros de paz resultó crucial para otros ámbitos fronterizos americanos. El conflicto que generaría la mayor transformación de la diplomacia fronteriza sería el de la Araucanía, experimentando, a partir del tratado de Quillín de 1641, un drástico cambio que obligó a las administraciones virreinales y coloniales, así como a la propia corona, a adoptar una nueva política hacia el indígena no dominado, como el respeto a su propiedad territorial y costumbres a cambio de convertirse en vasallos del Rey libres de encomienda. Dentro de esta diplomacia fronteriza hay que resaltar los enormes cambios que trajeron dos grandes hechos históricos: la llegada de la dinastía de Borbón a la corona de España (1700) y la expulsión de la Compañía de Jesús (1767). A continuación vamos a examinar dos regiones fronterizas que experimentaron casos muy diferentes: el Chaco, que vivió el cambio de la dinastía real y la expulsión jesuita, y las posesiones de Norteamérica, sujetas a los dictados de la política europea.

\section{LA PROBLEMÁTICA DE LA PAZ EN EL GRAN CHACO.}

El ámbito humano y geográfico del Gran Chaco se caracterizó por ser un territorio acorralado por los asentamientos españoles pertenecientes a la Gobernación de Tucumán y las Audiencias de Charcas y Buenos Aires. El norte de la región, único espacio libre de presencia hispanocriolla, estaba delimitado por las belicosas tribus chiriguanas que habitaban los contrafuertes orientales andinos, acérrimos enemigos de algunas de las comunidades chaqueñas de la periferia

R. I., 1999, n. ${ }^{\circ} 217$ 
noroccidental. Las características naturales de esta región propiciaron la afluencia de varios grupos indígenas que habían sido empujados en época prehispánica por otras etnias amerindias y, finalmente, por la llegada de los españoles. Los excelentes estudios que ha realizado la etnohistoriadora Beatriz Vitar ${ }^{11}$ sobre la dinámica de las tribus que quedaron encerradas en el ámbito interior chaqueño, han sugerido que algunas tribus del Gran Chaco polarizaban su actividad guerrera fundamentalmente en torno al control de los alimentos. Las variadas condiciones climatológicas del hinterland del Gran Chaco, en las que se alternaban amplios períodos de sequía con devastadoras inundaciones, habían obligado a los grupos cazadores-recolectores guaycurú a desplazarse por el territorio en busca de la caza, actividad que compaginaban con la recolección de la algarroba y otros productos selváticos. Atendiendo a las incidencias climatológicas del Chaco y a la carestía de alimentos, dichos grupos alternaban estos movimientos migratorios con esporádicos asaltos a los pueblos semisedentarios de la periferia (lule-vilela y mataco-mataguayo) para apoderarse de sus provisiones de maíz, legumbres y calabaza. Los españoles encontraron a estos grupos habitando la periferia noroccidental y suroccidental del Chaco, después de haber sido expulsados de sus antiguos asentamientos por los toba, abipón y mocoví que prefirieron radicarse en las márgenes de los ríos Bermejo y Pilcomayo, en el interior boscoso, hostil y selvático del Chaco.

A este proceso migratorio, iniciado antes de los primeros años del siglo XVI se le unió, en la segunda mitad de la centuria, el progresivo avance del proceso colonizador español que comenzará a cercar con sus asentamientos los límites este, sur y oeste del Gran Chaco. Algunos años más tarde, los enclaves españoles de la Gobernación de Tucumán, la Audiencia de Charcas y Buenos Aires se convertirían en el nuevo blanco de sus ataques. En realidad, la presión que ejercieron las diferentes naciones indias sobre los recursos del Chaco derivaron en un problema de abastecimiento que se vio solucionado por la incorporación de productos alimenticios de origen español, fundamentalmente la carne de vacuno de la que los grupos guyacurú se volvieron muy dependientes. Esta nueva fuente de alimentación se conseguía mediante el robo o la entrega voluntaria por parte de misioneros y ciudades. Sin embargo, y a diferencia del espacio fronterizo chichimeca, el ámbito chaqueño, a causa de la creciente dependencia alimenticia indígena, se caracterizó por una continua traslación de la frontera en la que los núcleos urbanos se convirtieron en la primer línea de defensa $-\mathrm{y}$ frecuente objeto de saqueo- de las incursiones indígenas procedentes del Gran Chaco. Descartada la existencia de metales preciosos, a los ojos de los primeros conquista-

11 Beatriz VITAR, «Las relaciones entre los indígenas y el mundo colonial en un espacio conflictivo: la frontera tucumano-chaqueña en el siglo XVIII», Revista Española de Antropología Americana, $\mathrm{n}^{\circ 21}$. pp.243-278, Edit. Univ. Complutense, Madrid. Idem:Guerra y Misiones en la frontera chaqueña del Tucumán (1700-1767), CSIC, Madrid, 1997. 
dores el único atractivo que presentaba esta región era la pretendida feracidad que la leyenda atribuía a las tierras mesopotámicas del interior ocultas por las selvas de espinos y cuya mejor evidencia eran los fértiles campos que circundaban la región. Este fue el principal argumento que se había esgrimido en la colonia para demostrar la irreductibilidad de los guaycurú, pero las repetidas incursiones punitivas hispanocriollas del siglo XVIII demostraron que era falso. Por ello, ya antes de sufrir las primeras oleadas de ataques, la mayor parte de las huestes conquistadoras encaminaron sus pasos hacia el atrayente Chile y no sería hasta la activación del foco minero del alto Perú cuando la región alcanzara notoriedad y, de hecho, la Gobernación de Tucumán se fue convirtiendo en un territorio clave para la economía del virreinato peruano. Las producciones agrícolas y ganaderas de aquella provincia se destinaban en su mayor parte al aprovisionamiento de las minas del Perú: vacas, mulas, ropa, peonaje y alimentos. Este encadenamiento económico con el polo minero de Potosí dio lugar al desarrollo de un pujante frente estanciero y agrícola que cada vez iba ocupando los territorios colindantes a las chacras y zonas de caza de los indígenas chaqueños ${ }^{12}$. La acción colonizadora del hombre blanco en la periferia del Chaco, fue iniciada en el siglo XVII desde la Gobernación del Tucumán; siguiendo una dirección de sur a norte, tenía como objetivo inicial la dominación de los territorios habitados por los grupos fronterizos. Una vez dominados, estos reductos serían utilizados como base para las operaciones de subyugación de las tribus del interior del Chaco que ya amenazaban con sus correrías la floreciente economía de la Gobernación. La creciente presencia de los españoles en la periferia daría lugar a que se produjeran nuevas migraciones tribales, acompañadas de profundas transformaciones de las sociedades chaqueñas. La más importante provino de la distinta adopción del caballo por parte de los indígenas, lo cual le serviría a la colonia para diferenciarlos entre grupos pedestres (lule,vilela y mataco-mataguayo) menos belicosos, y los ecuestres guaycurúes, más violentos y, paradójicamente, más apreciados por sus habilidades físicas por los misioneros jesuitas pese a las enormes dificultades que tenían para reducirlos. La incorporación del caballo incrementó la movilidad y agresividad de los guaycurúes y la captura de sus manadas se convirtió en uno de los objetivos principales de las expediciones hispanocriollas. Por otro lado, la creciente presencia de los españoles en los márgenes del Chaco dio lugar a la toma de contactos con elementos de la cultura hispanocriolla de los que los indígenas empezaron a tener una enorme dependencia. Las crónicas jesuitas se refieren con todo lujo de detalles a los importantes festines que los indígenas reducidos hacían con el ganado que se les entregaba pero también señalan la escasa importancia que le daban a la posibilidad de preservar sus fuentes de alimentación. El desinterés de los indígenas por asegurarse la reproducción de las fuentes de alimento radicaba en el conocimiento que tenían de que los misioneros

\footnotetext{
12 VITAR, Las relaciones... [11] p. 244.
} 
se lo proporcionarían para asegurarse su permanencia en la reducción. Si alguna vez se les reprochaba su actitud respondían altaneramente que siempre podían volver a las selvas a alimentarse de la caza, aunque la realidad - y el hambreles volviera a atraer a la misión ${ }^{13}$.

Coincidimos con Beatriz Vitar en que una de las transformaciones más importantes que experimentaron los indígenas chaqueños fue la creación de confederaciones en las que los líderes bélicos y los grupos de guerreros tuvieron un importante papel a la hora de dirigir la confrontación contra la creciente presión española. Especialmente relevante es la importancia que adquirieron después de 1770 algunos jefes indígenas a quienes se privilegia aún más por el ascendente que ejercen entre los aborígenes. Encontramos un buen ejemplo en Paykin, a quien se le denomina como primer caporal o jefe de las naciones del Gran Chaco Gualamba, o el caso de Colompotop ${ }^{14}$.

El problema de la contención de los ataques chaqueños a la importante economía colonial que se desarrollaba en las regiones adyacentes partía de la propia colonia. En el caso concreto del Tucumán, Juan Carlos Garavaglia ha analizado la existencia de tres grandes grupos interesados en la reducción de los indígenas: los hacendados ganaderos, los gobernadores militares y la Compañía de Jesús ${ }^{15}$. Todos ellos dirigen sus esfuerzos y atenciones hacia los indígenas, pero con objetivos muy diferentes y, la mayoría de las veces, con carácter excluyente. A lo largo de los siglos XVII y XVIII actuaron descoordinadamente y, en no pocas ocasiones, abiertamente enfrentados. Antes hemos argumentado que el frente que se opuso al indígena belicoso fue mixto - militar y religioso-, pero hubo bastantes diferencias de planteamiento y concepción de la labor reduccional. Esta serie de divergencias fueron los motivos por los que la acción del frente colonial se restringió a una política puramente defensiva y no comenzó a ser efectiva hasta el siglo XVIII. Para poder asegurar el paulatino avance del frente pastoril hispanocriollo, los gobernadores tuvieron que echar mano del intento jesuita de establecer un cordón reduccional en torno al Gran Chaco y apoyarlo con presidios militares servidos con los sectores más marginales de las ciudades. La piedra angular de ese sistema defensivo se pretendía que la formaran los indios amigos provenientes de las reducciones de aborígenes más proclives al contacto español ${ }^{16}$. Como dato relevante respecto a otros ámbitos fronterizos de América Hispana contenidos en este trabajo, hemos de señalar que a estos aliados se les entregaba armas -incluso de fuego- y recibían instrucción militar. Pero lo más interesante es que, además, estos escuadrones indígenas provenían en su mayor parte de la política de pactos o agasajos que se había llevado a cabo dos siglos antes.

13 VITAR, Guerra y Misiones... [11] pp. 82-83.

14 Idem, p. 113.

15 Juan Carlos Garavaglia, Guerra en el Tucumán colonial: Sociedad y Economía en un área de frontera, HISLA, n4, pp. 35-47, Instituto de Estudios Peruanos, Lima, 1984.

16 VITAR, Guerra y Misiones... [11] p. 27. 
Abelardo Levaggi menciona que, en el siglo XVI, hubo acuerdos verbales entre Alvar Núñez Cabeza de Vaca y los indios agaces - pertenecientes al hostil grupo guaycurú - yapirúes y aperúes encaminados a preservar a la ciudad de Asunción y a los guaraníes de sus ataques ${ }^{17}$. Aunque los indios reconocieron la soberanía española y entregaron rehenes, los acuerdos se pueden enmarcar dentro de las lábiles alianzas indígenas de la frontera americana. En la tradición pactista prehispánica, los aborígenes tratan de asegurar una paz momentánea para conseguir una posición ventajosa desde la que se pudiera escapar a un lugar seguro, rescatar a los rehenes dados en garantía - como en este caso- o reunir nuevas fuerzas para atacar. Hubo un nuevo acuerdo verbal, junto con entrega de rehenes, en 1619. Varios grupos guaycurúes de las márgenes del Bermejo acordaron la paz con el padre jesuita Juan de Argüelles, pero hemos de esperar a la segunda mitad del siglo XVII para poder tener acceso a un documento formal de un acuerdo diplomático suscrito el trece de diciembre de 1662 entre Alonso de Mercado, gobernador del Río de la Plata y los tocagües y vilos. Este documento refleja el establecimiento de unas capitulaciones que muestran gran parte de la dinámica diplomática que se va a llevar a cabo con el resto de los grupos indígenas del Gran Chaco durante el gobierno de los Austrias: reducción forzosa junto a un núcleo habitado español, indulto general de los delitos pasados, exención de encomienda y mita, y subordinación al poder real y sus representantes locales. Tenemos que esperar al inicio de la ofensiva hispanocriolla sobre el Chaco en el siglo XVIII para abordar la verdadera naturaleza de los encuentros diplomáticos.

Según Beatriz Vitar, el nuevo cambio de estrategia llevado a cabo por las fuerzas militares hispanocriollas en esa centuria perseguía tres objetivos bien definidos: neutralizar las ofensivas aborígenes mediante ataques certeros a sus habitats naturales, frenar la afluencia de los malones (asaltos) mediante la creación de un cinturón de protección formado por los pueblos chaqueños más dóciles (lules y vilelas) para que suministraran peones para las haciendas, e iniciar el establecimiento de una ruta de comunicación entre el Perú y la banda atlántica. Para la creación de este territorio colchón entre los indígenas más hostiles y los asentamientos españoles se comenzó a civilizar a los indígenas cuyas costumbres sedentarias les habían empujado a la periferia entre la presión de los hispanocriollos y los belicosos guaycurú. Con ellos se empezó a practicar la política de paces, como la llevada cabo por el gobernador Gaspar de Barahona en $1703^{18}$, pero la política diplomática comenzó a tener más entidad con el inicio de la guerra ofensiva llevada a cabo por el gobernador Esteban de Urízar y Arespacochaga en

17 Abelardo Levaggi, Tratados entre la Corona y los Indios del Chaco. Homenaje a I. Sánchez Bella, (Coord. Joaquín Salcedo), Servicio Publicaciones Universidad Navarra, Pamplona, 1992, pp. 294 y ss.

18 El gobernador Gaspar de Barahona informa sobre las paces establecidas con los indios lules cuando estaban reparando el cauce del río Salado, Salta, 6 de diciembre de 1703, Archivo General de la Provincia de Santiago del Estero. AG, Legajo 1, Expediente 3. 
1710 y 1711. Urízar, con sus expediciones al Chaco, quería obligar a las comunidades indígenas a retirarse al interior para que aumentaran las fricciones interétnicas y los grupos guaycurú dejaran de hostigar a las recientes comunidades de los indios reducidos. Como ha señalado Vitar, el gobernador, para poder enganchar voluntarios a su expedición, promovió la codicia de los hispanocriollos esgrimiendo el mismo argumento que había empleado Ángel de Peredo en su entrada del siglo XVII: el reparto de los indígenas capturados en el combate, propuesta que había sido aceptada por las autoridades civiles y religiosas. El plan del gobernador contemplaba la posibilidad de que, en un futuro, los indios reducidos junto a los presidios españoles alcanzaran el suficiente grado de civilización como para que integraran un cuerpo de soldados auxiliares destinados a transportar la impedimenta y combatir a los indígenas indómitos; en definitiva, crear un cuerpo militar de indios amigos.

La primera entrada se realizó en 1710 y se saldó con un éxito rotundo; Urízar aprovechó la ventaja militar obtenida en la campaña para obtener unas paces ventajosas con lules, ojotaes y malbalaes. Éstos últimos fueron los primeros en solicitar la paz a los españoles para lo cual se valieron de un indio ladino que sirvió de mediador e intérprete con el cacique Jonasteté para el asiento de las capitulaciones. En este acuerdo se reflejan la mayor parte de las obligaciones que a partir de ahora van a suscribir todos los indios del Chaco que realicen tratados con los españoles: benévolo perdón de las autoridades y, en calidad de vasallos del Rey, obligación de reducirse en un paraje determinado donde aceptarían la presencia de misioneros y la ayuda de los criollos para aprender la agricultura y se les proveería inicialmente de alimentos. También se les proporcionaría cobertura militar en el caso de que fueran atacados por comunidades enemigas, pero los malbalaes se comprometían a avisar de los ataques de indios hostiles y apoyar a los españoles en la contención de los malones. Los indios del Gran Chaco tenían una estructura sociopolítica atomizada en la que el jefe dirigente tenía el escaso poder que le proporcionaba su prestigio y valor personal. Por ello, los hispanocriollos también intentaron privilegiar a los cuadros dirigentes con el fin de garantizar la estabilidad de la paz y la continuidad de la reducción mediante una imposición vertical. El padre Lozano dice que se hizo entrega de insignias y vestidos al cacique Jonasteté y a los capitanes de guerra más destacados antes del parlamento, y durante su celebración se les concedieron cargos honoríficos y los ansiados bastones de mando, símbolo de la autoridad española.

El acuerdo se solemnizó con la entrega que hizo Jonasteté a Urízar de un dardo muy lucido. Al resto de los indígenas reducidos se les regalaba alimentos, yerba mate, tabaco y vestidos. Beatriz Vitar ha puesto de relieve el importante comentario que hace el padre jesuita Lozano respecto a que, a la hora de privilegiar a los caciques en las reducciones, se debía de hacer mediante la adjudicación de las tierras de mejores calidad, con el fin de que, incitados por los resultados de su feracidad, arrastraran al sedentarismo a un pueblo exclusivamente nómada 
como el malbalá19. En los acuerdos concertados con los lules del cacique Coronel, los delegados de Urízar estipularon que debían hacer la paz con los malbaláes recién apaciguados y se precisa que todos estos indios de las reducciones se convertían en vasallos directos del Rey y quedaban exentos de la mita ${ }^{20}$. Radicados en la misión jesuita de Miraflores, los lule fueron rápidamente introducidos en la dinámica fronteriza puesto que se les repartieron caballos para que se fueran ejercitando en el arte ecuestre y, como aliados de los españoles, recibieron entrenamiento militar para que, en calidad de indios amigos, hicieran frente a los grupos guaycurú. Con este grupo de belicosas naciones indias las dos expediciones organizadas por Esteban Urízar obtuvieron resultados diversos, demostrándose que los mocobí eran los más reacios a abandonar sus territorios y reducirse a los postulados españoles. Fue tan grande su resistencia que llegaron incluso a soliviantar a los malbalaes reducidos en Valbuena, quienes abandonaron su asentamiento para volver a la selva. Para los hispanocriollos, esta ruptura de los acuerdos engrosó la amplia casuística fronteriza americana en la que los indígenas se «caracterizaban» por la infidelidad a la palabra dada. Las expediciones de Urízar no se volverían a repetir en lo que restaba de su mandato y, aunque la colonia no continuó con el frente ofensivo por las disensiones internas surgidas entre los hacendados y la población a la hora de sufragar las expediciones, su combinación político-diplomática se convirtió en el modelo a seguir por los gobernadores posteriores $^{21}$. El período 1724-1735 se caracterizó por el acantonamiento de las fuerzas en los presidios y la realización de urgentes obras de rehabilitación. No obstante, en esta etapa hubo ocasiones en las que las sinceras ofertas de paz ofrecidas por los indígenas a ciudades periféricas del Chaco no pudieron ser aceptadas por la incapacidad que tenían los moradores de abastecer de medios y alimentos a la reducción que se pretendía fundar, tal y como ocurrió con los cinco representantes vilelas y los vecinos de Santiago del Estero en 1728.

La diferencia fundamental de la frontera chaqueña respecto al resto de los ámbitos limítrofes hispanoamericanos es que, debido a su carácter nómada, los indios no consideraban que los acuerdos suscritos entre una comunidad chaqueña con una ciudad concreta debían de hacerse extensivos al resto de los enclaves hispanocriollos. Es más, cuando empezaron a evaluar las características de la dinámica diplomática fronteriza, se valieron de las garantías de paz proporcionadas por los vecinos de una región para escapar a las represalias de algunos malones efectuados en otros asentamientos españoles o atacar con seguridad a sus

19 Pedro LozAno, Descripción corográfica del Gran Chaco Gualamba, Instituto Nacional de Antropología de la Universidad de Tucumán, Tucumán, 1941, p.356. Citado por VITAR, Guerra y Misiones... [11] p. 187.

20 Pedro Francisco Javier de Charlevolx .Historia del Paraguay, Traducción de Pablo Hernández, 4 vols, Madrid, 1913.

21 VITAR, Guerra y Misiones...[11] p. 191.

R. I., 1999, n. 217 
enemigos $^{22}$. Los aborígenes sabían por los indios ladinos y mestizos que los hispanocriollos se veían obligados a obviar el incidente para conservar la buena armonía con lo indígenas reducidos, so pena de ser el futuro objeto de saqueo de los guaycurúes del interior del Chaco o romper las relaciones laborales y económicas que encomenderos y vecinos mantenían con los indígenas chaqueños.

Al igual que en el mundo indígena de la Pampa y la Araucanía, la afluencia de elementos materiales de la cultura europea al seno de las comunidades chaqueñas estaba provocando una sucesiva dependencia que determinó la aceptación de las paces y su reducción - o la continuidad de la guerra - en la medida en que podían satisfacer sus necesidades. En el momento en el que el suministro de alimentos y productos europeos se interrumpía o los jóvenes guerreros tenían posibilidad de realizar un malón provechoso, se rompían los pactos y la comunidad abandonaba la reducción. Pese a todo, la política de persuasión pacífica fue dando sus frutos entre las comunidades guaycurúes más débiles que fueron asentándose cerca de los fortines españoles, o grupos mbayás y payaguás que en 1740 firmaron con Rafael de la Moneda, gobernador de Paraguay, su reducción junto a la ciudad de Asunción y una alianza militar ${ }^{23}$.

La frontera chaqueña tuvo un nuevo impulso a mediados de la centuria con Juan Victorino Martínez de Tineo, gobernador del Tucumán, que se mostró partidario de realizar continuas entradas en el Chaco a partir de una línea de fortines notablemente reforzada. Este gobernador y sus subalternos tuvieron ocasión de concertar varios acuerdos y treguas con comunidades mataguayas, malbaláes, tobas y abipones. Martínez de Tineo fundó varios pueblos destinados a ser administrados por la Compañía de Jesús y protegidos por nuevos fortines. Las capitulaciones acordadas con los malbaláes en 1750 nos pueden servir para saber, en esencia, qué se les exigía a estos pueblos: atenerse a la vida sedentaria de la reducción y obedecer a los misioneros, ser aliados de los españoles y avisar de cualquier incursión hostil y, por último, ser fieles vasallos del Rey ${ }^{24}$. Como en otras ocasiones, el acuerdo no fue respetado por los indios que abandonaron la reducción en cuanto las circunstancias les fueron favorables. Sin embargo, desde el gobierno de Martínez de Tineo, los indígenas del Gran Chaco empezarían a sufrir un creciente acoso de los hispanocriollos que se constató por la confirmación de paces que llevó a cabo Francisco de Pestaña, sucesor de Tineo, y la importancia que estaba cobrando la región como territorio de comunicación entre el Alto Perú y el Atlántico a través del río Bermejo, objetivo en el que estaban involucradas las gobernaciones de Tucumán, Paraguay y Buenos Aires.

22 A. Gullón ABAO, La frontera del Chaco en la gobernación del Tucumán (1750-1810), Servicio Publicaciones Universidad de Cádiz, Cádiz, 1993, p. 93.

23 LeVAGGi [17] p. 310.

24 Idem, p.311. 
El plan consistía en una invasión conjunta del gobernador tucumano Espinosa y Dávalos y el Bonaerense Pedro de Ceballos; su objetivo era el corazón de la región selvática donde tenían sus moradas los grupos abipones y mocobíes que se mostraban más renuentes a la reducción. Beatriz Vitar ha señalado que, dados los cruciales objetivos que se perseguían con esta expedición, se dieron instrucciones específicas sobre los acuerdos de paz que se suscribieron con los indígenas. A partir de 1759, fecha en la que se iniciaría la expedición conjunta, se debía abandonar la diplomacia improvisada que se había llevado a cabo hasta ese momento y que, para la mayor parte de los los estamentos coloniales, no había generado mas que retrasos por las continuas traiciones de los indios a la palabra dada. Ahora se exigía una presión sobre el indígena que garantizara una paz durable y fir$m e$, pero dejando claro que los medios utilizados para conseguirla tenían que ser los mismos que dicta el derecho natural ${ }^{25}$. La expedición constituyó un éxito porque se garantizó el inicio de la reducción de tribus toba, mocobí y mbayá, mientras que grupos mataguayo que habían pactado con los españoles antes de 1759 y se habían rebelado, accedieron a mantener buenas relaciones con los hispanocriollos. Pese a las buenas expectativas conseguidas en las entradas de Espinosa y Ceballos el proyecto de trazar una línea de comunicación chaqueña con el Atlántico fue desechado por la administración central; ello supuso un freno en el avance hacia el interior que fue aprovechado por los grupos guaycurúes para realizar una ofensiva contra las gobernaciones periféricas que obligaron a la realización de nuevas entradas punitivas entre 1760 y 1767. En estas acciones se alternó la presión militar con una política de agasajos dirigida a los principales jefes indígenas, a quienes se les obsequiaba con ropas españolas y otorgaba títulos militares hispanocriollos. Esta continuidad en el acoso del Gran Chaco por parte de las expediciones hispanocriollas se produjo en un contexto de convulsión tanto en el mundo colonial —expulsión de la Compañía de Jesús- como en el indígena -la transformación sociopolítica chaqueña.

$\mathrm{Al}$ igual que en el resto de los ámbitos fronterizos americanos, el año 1767 supuso una enorme alteración para la diplomacia chaqueña con el destierro jesuita. El fracaso del programa de creación de misiones/fuertes en el interior del Gran Chaco obligó a los jesuitas a instalar sus dependencias en la periferia de la región. Estos establecimientos se convertirán en los puntos de partida de sus entradas al interior del Chaco a la vez que en puntos de captación para la reducción de futuros aborígenes. A diferencia de otras fronteras en el Gran Chaco los jesuitas no jugaron un papel diplomático tan determinante pero fueron muy hábiles a la hora de sacar partido de las prerrogativas que les habían concedido en su política misionera, aportando a la frontera su propia fuente de pacificación. La exención de cumplir con la mita y ser reducidos al régimen de encomienda a

25 Instrucciones para la entrada general a las tierras del Chaco. San Borja, 9-XII-1758. Archivo General de Indias, Buenos Aires 18, Citado por VITAR, Guerra y Misiones... [11] p. 205.

R. I., 1999, n. $^{\circ} 217$ 
cambio de autodefenderse fue aprovechada por los jesuitas para crear una variedad de indios amigos muy particular en el contexto fronterizo americano. Lejos de constituir comunidades indígenas que estaban sometidas política y administrativamente al gobierno local y que apoyaban al ejército hispanocriollo contra los indígenas rebeldes, los jesuitas constituyeron en las reducciones chaqueñas verdaderos escuadrones militares que estaban dotados de caballos y armamento europeo -incluso armas de fuego. Estos contingentes privados fueron empleados exitosamente contra el ataque de indios hostiles y a menudo los misioneros de las reducciones refieren en sus crónicas el éxito que habían tenido sus indios a la hora de rechazar el ataque de un grupo hostil. La experiencia reduccional les sirvió a los jesuitas para conocer mejor la idiosincrasia política y cultural de los indígenas del Chaco pero, si bien hicieron progresos notables con los grupos lule y vilela, y actuaron como intermediarios en algún acuerdo de reducción, encontraron enormes dificultades con los abipones y mocobíes por la atomización política de sus sociedades. A diferencia de la Araucanía, los jesuitas no tuvieron que ser desplazados del frente de negociación con el indígena puesto que se había llevado a cabo conjuntamente con la administración militar desde un principio. Sin embargo, sus prerrogativas en las reducciones fueron las que suscitaron las discrepancias con el resto de los estamentos coloniales y su expulsión no garantizó el avance hacia el control del mundo chaqueño, tal y como sus sucesores en la obra misionera tuvieron ocasión de comprobar.

El otro factor de desestabilización de la frontera chaqueña se estaba produciendo en el seno de la propia sociedad indígena. El contacto continuado que habían mantenido aborígenes y europeos desde la llegada de estos últimos a la periferia del Gran Chaco se había traducido en la progresiva incorporación de elementos económicos y materiales por parte de los indígenas chaqueños. Los más relevantes fueron el ganado vacuno y ovino como fuente importante de una dieta tradicional amenazada por la escasez y, quizás el más relevante, la importancia del caballo como medio de transporte y ataque. En un primer momento, el ganado equino había sido adaptado perfectamente a las necesidades nómadas de los grupos belicosos del Gran Chaco, facilitando el desplazamiento por el interior y los malones a los establecimientos y reducciones. Pero esta incorporación también constituyó un incremento del ethos guerrero y, en consecuencia, de las tensiones internas indígenas que se agravaron cuando el frente colonizador abandonó su actitud defensiva y adoptó una postura ofensiva reflejada en la entradas punitivas. Antes de las grandes incursiones organizadas por Urízar y Martínez de Tineo, los grupos indígenas guaycurú tenían posibilidades de mantener contactos e intercambio de información y bienes con comunidades reducidas inicialmente que, ante la sospecha de connivencia con los indígenas hostiles, podían abandonar la reducción. Pero, a medida que el frente estanciero iba progresando hacia el interior, las reducciones eran mejor protegidas por los fuertes o sus partidas de autodefensa armadas por los jesuitas. Así, los grupos chaqueños más díscolos se 
vieron obligados a reforzar el papel de sus líderes guerreros y conformar alianzas con los otrora enemigos para hacer frente al enemigo común. Los hispanocriollos fueron muy conscientes del papel que empezaron a adquirir estos líderes puesto que, sin ser determinantes en la desestructurada sociedad chaqueña donde cada hombre era un líder en potencia, podían influir entre sus iguales con su capacidad de oratoria; de ahí que les agasajaran, vistieran y concedieran prebendas aunque se obtuvieron magros resultados. Pese a todo, a medida que el cerco colonial se fue estrechando sobre el Gran Chaco, se empieza a observar en la diplomacia una concentración del poder en algunos caciques representativos de la autoridad y confianza indígena, como ocurrió con el acuerdo suscrito con Paikín. Los españoles, durante el parlamento con este cacique, lo entendieron así cuando afirmaban que a Paykín le reconocen los demás por su primer Caporal.

Durante la década de los setenta los grandes cambios que se produjeron en España y América a raíz de la implantación de las reformas borbónicas, así como las nuevas directrices de la geopolítica internacional, también afectaron al Gran Chaco. El peligro de la expansión portuguesa a través de los bandeirantes ya se había hecho patente en el piedemonte oriental andino. Por otro lado, la posibilidad de que accedieran al Alto Perú a través de la ruta fluvial del Bermejo fue una de las razones que abortaron las buenas perspectivas de crear una red viaria extraídas a raíz de la misión conjunta Espinosa-Ceballos. Después de que se hubiera puesto en vigor el Tratado de Permuta por el que Portugal ocupaba la región comprendida entre los ríos Uruguay e Ibicuí, se tomaron medidas tendentes a asegurar que los portugueses no sólo no pudieran entrometerse en territorio español y realizar contrabando, sino también evitar que pudieran aliarse con las comunidades chaqueñas más hostiles a los españoles. Como ha apuntado Beatriz Vitar, desde ese momento las autoridades hispanocriollas se vieron compelidas a consolidar la frontera frente a los feroces guerreros guaycurúes a fin de contrarrestar la ulterior amenaza lusa ${ }^{26}$. En definitiva, a los gobernadores de las regiones limítrofes no se les dejaba otra opción que rehacer el frente misionero - que había quedado maltrecho tras la expulsión jesuita- y reanudar las expediciones militares pacificadoras al interior de la selva.

Pese a este complejo contexto político, la administración virreinal y central replanteó la posibilidad de volver a conectar Perú con los territorios del futuro virreinato del Río de la Plata para asegurar la posibilidad de que, en caso de ataque exterior, hubiera fluidez en las comunicaciones y el traslado de las milicias. Para ello había que garantizar una paz estable con los indígenas díscolos del Chaco; la Corona alentó la reanudación de las acciones del doble frente militar y religioso, promoviendo la reducción de los aborígenes junto a los enclaves hispanocriollos. Para ello, Gerónimo de Matorras, gobernador de Tucumán, empezó a organizar una nueva expedición al Chaco bajo las directrices de la exitosa entrada

26 VITAR, Guerra y Misiones... [11] p. 306. 
realizada por Espinosa y Dávalos, pero con la ambición de extender el frente estanciero y reduccional mucho más al interior. La expedición de Matorras (1774), alentada por las nuevas directrices borbónicas y la amenaza portuguesa, bien podía haberse realizado con objetivos militares precisos como el exterminio a sangre y fuego del indígena, tal y como clamaban los ricos hacendados y estancieros. Sin embargo, el gobernador tucumano no había dejado de calibrar la experiencia de sus antecesores en las entradas punitivas y supo valorar la verdadera envergadura de uno de sus principales enemigos, los mocobí.

En este sentido, tanto Alberto Gullón como Beatriz $\operatorname{Vitar}^{27}$ han resaltado la especial singularidad que tiene el tratado realizado entre Gerónimo de Matorras y varios caciques mocobíes entre los que se destaca Paykín por el trato excepcional que recibe. Ambos autores han reseñado la importancia que las autoridades hispanocriollas le dan a Paykín, ya que consideran que ahora sí se encuentran ante un representante político de varias comunidades indígenas a quien se le agasaja y regala con profusión debido a las posibilidades que hay de mantener con él un diálogo político directo que garantice los acuerdos suscritos. Sin embargo, también creemos que la preeminencia que ha alcanzado Paykín es producto del ascendente que a lo largo de su vida ha tenido entre los mocobíes y la habilidad de coordinar la lucha contra los hispanocriollos, pues éstos no en vano le han dado el título oficioso de Gran Caporal del Chaco. Una vez más nos encontramos con el hecho de que el proceso de evolución interna experimentado por los indígenas del Chaco como consecuencia de la presión española, así como la preeminencia política que desde el exterior se le confiere a algunos individuos conformó poco a poco - aunque en el caso chaqueño de una manera tardía - cabezas políticas dirigentes más o menos estables ${ }^{28}$.

Las ofertas realizadas por Matorras reconocían la posesión de las tierras que habitaban los mocobíes y, aunque se les ofertaba en las cláusulas 40 y 50 la posibilidad de reducirse en Santa Rosa de Lima en Tucumán, no se les obligaba a ello tan abiertamente como en tratados anteriores. Mediante este acuerdo los mocobíes se convertían en vasallos de Carlos III (cláusula 80) y quedaban exentos de encomienda (cláusula 20) asignándoles a Juan Antonio Caro como protector de indios para que, a través de él, pudieran realizar todas las peticiones o denunciar cualquier queja y abuso (cláusula 90). A cambio tan sólo se les pedía que aceptaran a los misioneros (30) y, como sucedió en la Araucanía y la Pampa, se les exhortaba a que firmaran la paz con los abipones para que las disputas internas indígenas no afectaran a las posesiones españolas. Esta cláusula encerraba el deseo de la Corona borbónica de garantizar un frente indígena sin fisuras ni disensiones que pudieran ser aprovechados por los enemigos de España para captar aliados. Los mocobíes solicitaron al gobernador que les entregaran armas blancas

\footnotetext{
27 GULLÓN [22] p. 99 y ViTAR, Guerra y Misiones...[11] p. 311.

28 LÁZARO [2] pp. 75 y ss.
} 
y de fuego para defenderse de sus enemigos, petición que les fue denegada por el gobernador hasta que hubieran dado muestras de su lealtad a la Corona. El tratado fue ratificado solemnemente con el abrazo del gobernador y los caciques con el redoble de tambores de fondo. En principio, puede parecer que en Paykín recayó todo el peso de las negociaciones con los hispanocriollos pero el acta muestra en todo momento la presencia del cacique Lachirikín como garante de la aceptación del resto de los mocobíes. Aun así, los documentos persisten en su deseo de transmitirnos la idea de que con Paykín, al fin, se había encontrado una cabeza dirigente con la que se podía negociar una paz, y trataron de asegurarse esa prerrogativa indicándole que sería perpetuo cacique de todas las parcialidades que lo seguían, con lo que, una vez más, se pone en evidencia el mecanismo hispanocriollo de crear jefaturas artificiales entre las sociedades de cacicazgos americanas con la tradicional entrega de bastones de mando. Pese a la importancia que la historiografía chaqueña le ha dado al acuerdo alcanzado con Paykín como prueba de la sumisión indígena a través de un cacique, conviene señalar que Matorras tuvo que acudir al asentamiento de un nuevo dirigente mocobí a ratificar las paces acordadas.

Todo lo que Gerónimo de Matorras capituló con Paykín fue aprobado por Carlos III mediante la cédula del 6 de septiembre de 1777 y la vigencia del tratado se mantuvo hasta la muerte de Paykín a mano de los abipones. Durante el gobierno interino del coronel Gabino Arias llegaron a Salta los caciques mocobíes y tobas encabezados por el cacique Queyacarí a comunicar la muerte de Paykín y ratificar las paces hechas. Con ellos traían el bastón con puño de oro que Matorras entregó a Paykín y que ahora devolvía su viuda por ser menores de edad los hijos y herederos que no podían desempeñar el cargo que otrora tuvo el Gran Caporal del Chaco. A través del franciscano Antonio Lapa, el bastón junto con sus prerrogativas - fue devuelto a los mocobíes y entregado en persona al cacique Queyaverí. El fraile añadía que Queyaverí le pidió que al día siguiente hiciese la misma relación en presencia de los demás caciques, lo cual demuestra hasta qué punto la distinción en la jefatura tribal - junto con la entrega de regalos simbólicos procedente del exterior - estaba empezando a calar entre los indígenas chaqueños. Investido con el nuevo título, el cacique mocobí viajó a Salta donde fue recibido por el Cabildo el 30 de julio de 1776.

La promulgación de la cédula de 1777 viene a ratificar la progresiva asimilación de las jefaturas chaqueñas representadas por el simbolismo de los bastones de mando. Es bastante probable que en la aparición de estas jefaturas políticas hayan coincidido tanto los deseos de los europeos como las crecientes necesidades indígenas de organizarse a nivel supracomunitario para defenderse de la creciente amenaza española y vehicular las relaciones políticas - y los regaloshacia las tribus. La asimilación y representatividad del poder indígena que tiene el bastón de mando se refleja perfectamente en las instrucciones del monarca borbón. El rey Carlos III pretendía que dichos grupos chaqueños se establecieran 
en el Paraguay en unas reducciones provistas de todo lo necesario para su supervivencia material y espiritual protegidos por un fuerte y milicias españolas (obligaciones 10,30 y 40). Sin embargo, en sus Instrucciones especifica que los indígenas reducidos deben empezar a valerse por sí mismos, y deja bien claro cuál es la misión de estas reducciones frente a una hipotética amenaza indígena o portuguesa: 50 Que su establecimiento deberá ser lo más inmediato a las márgenes de aquel grande río para poder con facilidad y prontitud oponerse a cualquiera invasión que otras naciones pretendan, así contra ellas como contra mis vasallos ${ }^{29}$.

Las directrices emanadas desde la metrópoli expresaban nítidamente el deseo de que el proceso de civilización inherente a los acuerdos diplomáticos persiguiese el establecimiento de un territorio defensivo de aborígenes aliados frente a los hipotéticos enemigos de la corona - ya fueran europeos o indígenas- y los establecimientos hispanocriollos con la premisa de que, una vez atraídos a la reducción con regalos de ropa, utensilios y ganado - donados sobre todo a los caciques - fueran los propios indígenas quienes se costearan su propia supervivencia. De esta manera, presionados por la intervención militar, se pretendía evitar la excesiva dependencia existente entre las reducciones indígenas de comunidades chaqueñas semisedentarias y la administración civil y religiosa. Siguiendo esas instrucciones Gabino Arias consiguió pacificar a los chunupíes, malbalaes y sinipíes.

Antes de finalizar con los acuerdos diplomáticos chaqueños, queremos hacer referencia a dos puntos estrechamente relacionados con el proceso de expansión hispanocriolla sobre el Gran Chaco. El primero de ellos se trata de las continuas alusiones que encontramos en la documentación sobre la peticiones de paz y envíos de embajadas por parte de los indígenas para aceptar reducirse y, en consecuencia, convertirse en vasallos de los españoles. Desde el punto de vista documental, la mayor parte de los textos y encabezamientos de las actas y legajos sobre los acuerdos de paz revisados para este trabajo dejan patente el hecho de que son los indígenas quienes «solicitan la paz». Políticamente, el refrendo escrito de esta petición surte un enorme efecto propagandístico a favor de los hispanocriollos, pues deja en evidencia la derrota de los indígenas. Aunque ya hemos tenido ocasión de examinar el hecho de que esta aseveración no siempre se cumplió en otros ámbitos fronterizos de la América Hispana, hemos de considerar que, en el Gran Chaco, un gran número de sus comunidades se vieron obligadas a solicitar la paz para poder sobrevivir, pero ello no implica una derrota político-militar. Las crónicas de los misioneros han dejado patente, que pese a la vanidad de los indígenas, la voracidad con la que consumían las provisiones que se les entregaba hacían pensar que las extremas condiciones medioambientales del Gran Chaco ejercían una fuerte presión sobre estas comunidades que se tra-

29 «Instrucciones del Rey Carlos III al virrey de las provincias del Río de la Plata acerca de los guaycurúes», en José ALUMNI, El Chaco (1750-1950), Resistencia, 1951.p. 267. 
ducía, como afirmaron Metráux y Susnik, en una evidente tensión bélica. Beatriz Vitar ya rebatió en su libro la falacia que alimentó la contínua expansión hacia el Chaco: su enorme feracidad capaz de alimentar a los contingentes de indios belicosos. Desde mediados del siglo XVIII, los expedicionarios descubrieron que los indígenas guaycurúes vivían en unas condiciones precarias, pero que el Gran Chaco constituía una fuente inestimable para la obtención de mano de obra barata y la explotación maderera. Así, la presión a la que eran sometidos los indígenas por las diferentes gobernaciones limítrofes se tradujo en la creación de confederaciones supracomunitarias dirigidas por guerreros de prestigio que encabezaran la lucha contra los españoles y posterioremente, ante la necesidad, pactaran con los hispanocriollos para poder sobrevivir. En este sentido, conviene tener muy en cuenta la propuesta que ha hecho Abelardo Levaggi sobre el caracter jurídico de los acuerdos establecidos en esta frontera: en su mayoría, podemos referirnos a ellos como verdaderos tratados porque, a partir de la segunda mitad del siglo XVIII, los indígenas se ofrecieron a reducirse sin haber sido derrotados militarmente, por lo que tenían un margen de negociación mayor que si hubiera sido una capitulación.

\section{NORTEAMÉRICA}

El primer año del siglo XVIII supuso la llegada de la dinastía de los Borbones al trono de España. Las fronteras de la América Hispana se caracterizaron por una situación en la que la política de parlamentos con los indígenas ya había empezado a adquirir unas dimensiones que rebasaron tanto los marcos de discusión estrictamente políticos y militares, como el espacio geográfico de la Araucanía, ámbito diplomático donde se desarrolló y consolidó el proceso pactista. No han transcendido datos suficientes como para poder afirmar que la experiencia chilena fuera asumida por la administración virreinal de Lima - y después por el gobierno de Buenos Aires- como el ejemplo idóneo para solucionar los conflictos fronterizos con los aborígenes americanos. Sin embargo, se registra la continuidad de la celebración de parlamentos y juntas de paz en otras regiones fronterizas conflictivas como el Gran Chaco $(1662,1703,1710,1727,1743,1746,1754 \ldots)$ y América del Norte $(1784,1793,1796$...).

Esta ampliación del ámbito de consenso también trajo consigo un conjunto de particularidades y excepciones. Ya hemos visto que en las relaciones consensuales establecidas con los grupos indígenas fronterizos del Gran Chaco volvió a actuar la combinación del frente militar y religioso - fundamentalmente los jesuitas - siendo estos últimos los principales mediadores entre los aborígenes y los poderes fácticos de la administración virreinal (funcionarios, gobernadores y militares). Por el contrario, en el caso de los territorios españoles de América del Norte, la diplomacia será mayoritariamente ejercida por funcionarios civiles y

R. I., $1999, \mathrm{n}^{\circ} 217$ 
militares, adquiriendo unas connotaciones muy diferentes a las del norte de México y el Chaco. ¿Cuáles fueron las razones que obligaron a la corona española a pactar cláusulas distintas en Norteamérica?

Conviene aclarar que la administración borbónica se había visto empujada a tomar serias determinaciones en lo que se refiere a sus posesiones septentrionales. Por ello, en su intento de preservar por completo los dominios de la Nueva España de las depredaciones francesas e inglesas, había creado la Comandancia General de las Provincias Internas (1776) y se había visto obligada a desplazar y organizar nuevas fuerzas que defendieran sus territorios septentrionales norteamericanos de ataques indígenas. Esta no era una tarea fácil, dado que tenían que controlar tanto a las desconocidas comunidades aborígenes que habitaban los nuevos dominios, como preservar el flanco oriental de la Luisiana de los ingleses a raíz de la guerra de los Siete Años y el tratado de París (1763). A estas funciones pronto se añadirían las misiones de vigilancia costera desde el puerto de San Blas ante los crecientes intereses comerciales que estaban demostrando los ingleses en la costa noroeste norteamericana y que culminarían finalmente en el incidente de Nootka (1790). Así pues, España se vio obligada a mantener una frontera indeseada frente a uno de sus más acérrimos enemigos europeos (Inglaterra), al que pronto se sumarán las colonias independientes de los futuros Estados Unidos. La administración borbónica se vio obligada a granjearse la simpatía de las organizadas comunidades indígenas de los choctaws, alibamones, talapuches, chicasas, etc., que bordeaban el Mississipi ${ }^{30}$. Para ello, y a sabiendas de que no tenía los suficientes recursos humanos y económicos como para controlar efectivamente el territorio y a sus habitantes recurrió al pacto con el indígena como una manera de crear un territorio colchón que amortiguara cualquier invasión extranjera.

Quizás fuera este carácter forzoso e indeseado el que le confiriera a la diplomacia norteamericana algunos caracteres excepcionales. Desde el establecimiento de los primeros tratados suscritos en 1784, las autoridades militares españolas siempre quisieron dejar patente su deseo de que los indígenas norteamericanos aceptaran en todo momento el vasallaje al rey de España, argumentando que, bajo su bandera y protección, vivirían a salvo de los ataques de cualquier enemigo europeo o indígena. Los indígenas así lo declararon y aceptaron, pero no por ello dejaron de introducir matices a lo convenido:

Artículo 11 Nosotros, los expresados Jefes de la Nación Talapuche, por nosotros y en nombre de los demás Jefes, Capitanes, Guerreros y demás individuos de ella de cualquiera edad, sexo o condición que sea, prometemos y nos empeñamos por el Dios Supremo, creador del Cielo y de la tierra, a quien es-

30 V. CORTÉS, Historia de los Indios del Sureste de los Estados Unidos durante la segunda mitad del siglo XVIII, Tesis Doctoral, Universidad Complutense de Madrid, 1966. 


\begin{abstract}
tán sujetas todas las cosas visibles e invisibles, en guardar y mantener una inviolable Paz y fidelidad con S.M.C., sus Provincias, súdbitos y vasallos, procurándonos recíprocamente cuantas ventajas puedan contribuir al interés y gloria de ambas partes contratantes. Ofrecemos exponer por el real servicio de S.M.C. nuestras vidas y haciendas, y prometemos obedecer las soberanas disposiciones que en caso necesario nos sean comunicadas por el Capitán General de las Provincias de la Luisiana y Floridas, y en su nombre, por los respectivos Gobernadores o Comandantes particulares de las expresadas Provincias, portándonos siempre en la mejor armonía, unión y buena amistad; pues desde este instante, de nuestra propia y espontánea voluntad prometemos obedecer las Leyes del Gran Rey de las Españas en aquellos que son compatibles con nuestro carácter y circunstancias.... ${ }^{31}$ (El subrayado es nuestro).
\end{abstract}

En la mayoría de los tratados norteamericanos aparecen suscritas cláusulas muy similares a la del resto del continente: impedir el robo de artículos y ganado de las estancias españolas, avisar a los militares de la infiltración de enemigos, paridad judicial para europeos e indios en los delitos, etc... Al igual que en el resto de las áreas fronterizas americanas, los hispanocriollos recompensaron a los dirigentes indígenas con regalos de ropa, tabaco, colorantes y abalorios, pero destaca sobremanera en el ámbito norteamericano la entrega de insignias militares y banderas del Rey de España que los indígenas gustaban de tremolar en sus festividades y cuando se acercaban a los fuertes españoles en son de paz.

Sin embargo, en todos los tratados, aparte del vasallaje al Rey, quedaba muy explícito el verdadero interés español en Norteamérica: el comercio. En este sentido, coincidimos con Abelardo Levaggi en el hecho sorprendente de que, a la hora de analizar los tratados suscritos con los indígenas norteamericanos, apenas hay alusiones a la labor evangelizadora entre los indígenas, elemento crucial de otras fronteras americanas ${ }^{32}$. En Norteamérica primó más el reconocimiento del vasallaje que le debían los indios a la corona española, así como el establecimiento de fluidas relaciones comerciales. Si analizamos el conjunto de textos de los tratados norteamericanos es evidente el interés de los negociadores españoles por conseguir escuadrones de indios amigos pero, por encima de todo, sobresale el objetivo de conseguir que estas tribus se conviertan en consumidores de productos españoles. Es cierto que no podemos simplificar todas las maniobras diplomáticas en Norteamérica a una cuestión exclusivamente comercial, pero no

31 Artículos convenidos en el Congreso celebrado en Panzacola los días 31 de mayo y 11 de junio de 1784 entre la Nación Española, representada por D. Esteban Miró, Gobernador de la Luisiana, D. Arturo O'Neil, Gobernador de Panzacola, y D. Martín Navarro, Intendente, y Alejandro Mac Gilibray [mestizo] principal representante de los indios Talapuches, Natchez y Chicasas. Archivo Histórico Nacional. Legajo 3885, Expediente 22, $\mathrm{n}^{\circ} 6$.

32 «Aplicación de la política española de tratados a los indios de la Nueva España y sus confines: el caso de la Luisiana y las Floridas (1781-1790)», Revista de Investigaciones Jurídicas, $\mathrm{n}^{\circ} 20$, México, 1996, p. 396.

R. I., 1999, n. ${ }^{\circ} 217$ 
por ello debemos dejar de tener en cuenta el hecho de que la administración española pudiera considerar su presencia en los territorios orientales americanos como una cuestión sujeta a los continuos cambios que imponían los pactos diplomáticos europeos. En este sentido, los territorios norteamericanos quedan parcialmente desvinculados de la tónica general de la diplomacia fronteriza americana, pero constituyen un buen ejemplo para constatar hasta qué punto el establecimiento de un ámbito de consenso podría ser efectivo aún en condiciones políticas tan precarias e interesadas como era el este de los Estados Unidos en la segunda mitad del siglo XVIII.

\section{CONCLUSIONES.}

El examen de estos tres ámbitos fronterizos nos ha permitido apreciar el grado de desarrollo de las relaciones diplomáticas establecidas con los indígenas no dominados de la América Hispana. Queremos advertir el hecho de que no podemos entender las reacciones de las administraciones locales, virreinales y centrales frente al fenómeno fronterizo de una manera aislada y que para ello debemos tener en cuenta el conjunto de acontecimientos surgidos en otras regiones fronterizas, fundamentalmente la Araucanía. Además, ambos bandos experimentaron su propia evolución y discurso a lo largo de los tres siglos de colonia.

En el caso del contexto americano, no debemos olvidar que, a pesar de los mutuos intereses que se escondían en las relaciones consensuadas de los parlamentos, el proceso de apaciguamiento y control de los conflictos fronterizos está marcado por una serie de rupturas violentas de los acuerdos, provocadas por los deseos de uno $\mathrm{u}$ otro bando de imponer sus intereses particulares o generales (dominar legal y fiscalmente a los indios libres, aumentar el área de protección de sus asentamientos, extender o preservar sus prerrogativas en los derechos a la captura del ganado cimarrón, intentos de reducción misional o institucional) o la presión de elementos foráneos como los enemigos de España en América (holandeses, ingleses y norteamericanos). Además esta relación fue fuente de problemas internos coloniales y metropolitanos tan espinosos como la licitud en declarar la guerra y esclavizar a los indígenas rebeldes, donde intervino activamente parte de la Iglesia encabezada por los jesuitas y los dominicos, elementos más activos del frente misionero. Visto con retrospectiva, este proceso parlamentario permite afirmar ahora que, con el paso de los años, paulatinamente se fueron cimentando las bases de la seguridad de los confines del imperio español en América, pero no puede ocultar el hecho de que, en aquella época, esta sucesión de parlamentos y rupturas de tratados acompañada de hechos violentos fueran contempladas con recelo por parte de hispanocriollos e indígenas, siendo objeto de controversia e inestabilidad, sobre todo porque les resultaba muy difícil reconocer que sus legendarios enemigos podían vivir en libertad en sus tierras, practi- 
cando sus costumbres ancestrales y, por si fuera poco, eran considerados como iguales dada su calidad de aliados y vasallos directos del Rey.

En el apartado metropolitano, la política de pactos americanos también experimentó su propia evolución. Cuando los reformadores borbónicos inician el proceso de implantación de las reformas centralizadoras en América, tuvieron que hacer frente tanto a las consecuencias de la política fronteriza del Antiguo Régimen que se había estado llevando a cabo exitosamente en la Araucanía, como a la manera de afrontar los viejos conflictos limítrofes cara al nuevo marco geoestratégico impuesto por los dictados del escenario político europeo. El problema más grave al que tenían que enfrentarse los reformadores borbónicos no sólo radicaba en las ansias expansionistas de Portugal en el estuario del Plata o las incursiones inglesas, holandesas y francesas en el Golfo de México y las posesiones norteamericanas, sino que ya habían experimentado en 1643 la posibilidad de que alguna potencia enemiga se instalara en confines tan alejados e incontrolados como el sur de Chile y se aliara con los indígenas. Además, los reformadores borbónicos pudieron constatar que los viejos problemas de límites que la corona española tenía con otras potencias coloniales europeas, así como sus intentos de preservar sus dominios de emplazamientos militares y comerciales extranjeros casi siempre coincidieron con territorios fronterizos cuyos dominios no estaban consolidados o que habían sido objeto de una reciente y débil colonización. Por si fuera poco, la nueva dinastía se encontró con el hecho de que la problemática fronteriza estab directamente relacionada con la mayor o menor intervención de la Iglesia.

Ante esta situación, pensamos que la primera reacción de la administración borbónica fue aceptar la situación heredada del pactismo del Antiguo Régimen y continuar la política de celebración de los parlamentos. Para ello, persistieron en la utilización de la combinación del frente militar y misionero en aquellas regiones donde habían demostrado un éxito notable (Araucanía y Chaco) e intentaron valerse de los religiosos para intervenir en aquellos otros ámbitos fronterizos donde sólo se había hecho uso de la fuerza militar, como en la Mosquitia y la Pampa, o donde aquélla no podía llegar, como en la Patagonia. Pero una vez que hubieron tenido el conocimiento necesario de la situación, intervinieron directamente en las negociaciones con los representantes indígenas fronterizos, tal como ocurrió en la Araucanía a mediados del siglo XVIII. Intervención en la que dejaron a un lado a la Compañía de Jesús, principales interlocutores de los siglos XVI y XVII, y frenaron los intereses criollos locales.

Antes de su entrada en el juego diplomático fronterizo, la administración borbónica tenía claro que, en ningún momento, desdeñaba la posibilidad de estrechar el control sobre estas comunidades aborígenes fronterizas por medio de un acuerdo pacífico reflejado en el parlamento. Este fue uno de los mecanismos empleados cuyo efecto a largo plazo era conseguir el control definitivo de los aborígenes libres mediante la persuasión y las donaciones de regalos, así como el empleo de aliados locales. En su política de control, la corona borbónica trató de 
ampliar el contenido y función política de aquellos grupos indígenas aliados - los indios amigos - con el fin de convertirlos en soldados fronterizos de la Corona. Esto sucedió en el caso de los pehuenches en Chile y la Pampa, los lules, vilelas y matacos en el Gran Chaco, y las diferentes naciones del Mississipi. El objetivo mediato de estos soldados indígenas era que sus territorios, establecidos cerca de las posesiones españolas, sirvieran como colchón para amortiguar las incursiones de otros grupos indígenas «rebeldes» o enemigos europeos de la Corona. De ahí deriva la preocupación existente en la administración respecto a las disputas internas de estas sociedades indígenas, por lo que la Corona intentó mediar interesadamente en esos conflictos con el fin de evitar la ruptura del equilibrio de poderes entre las diferentes tribus fronterizas. Esa mediación resultó compleja, ya que algunas comunidades indígenas buscaban. interesadamente la amistad con los hispanocriollos para dirimir sus disputas ancestrales con otros grupos. Las alteraciones provocadas por estas alianzas militares o los crecientes intereses originados por la liberaliżación comercial propugnada por la administración borbónica, acarrearían desagradables consecuencias para sus asentamientos fronterizos. Finalmente, el objetivo primordial que se perseguía con estos soldados fronterizos indígenas era que estuvieran dispuestos a rechazar militarmente cualquier invasión por parte de los enemigos europeos de España. En definitiva, la administración central española se vió obligada a asumir el fracaso de controlar a los indígenas fronterizos de sus dominios americanos pero, en el caso de los Borbones, supo hacerse con los resultados positivos obtenidos aisladamente en el Antiguo Régimen y reconducirlos, sin necesidad de contar con el determinante factor eclesiástico, hacia una empresa difícil: garantizar sus dominios territoriales mediante unos indígenas libres a los que tan sólo se les pedía el vasallaje a un Rey lejano.

This article evaluates the role played by the frontier conflicts in the adoption of policies which led to the creation of a diplomatic or consensual ambit. The first frontier conflict to be dealt with is that of Northern Mexico, through which the hasty solutions that had to be adopted for its resolution are studied. However these policies had a deep repercussion in the metropolis and they were applied and modified in later frontier conflicts such as that of the Chaco region, midway between the Austrians' and the Borbons' policies. Finally, I analyze the case of the North American Spanish possessions, where pactism was applied by the Borbons' reform policies which faced the difficult task of preserving their territorial dominions as well as their commercial interests in a complex political context. 